\title{
Imágenes epifánicas. Voces de la poesía chilena contemporánea*
}

\section{Claudio Guerrero Valenzuela**}

\begin{abstract}
Resumen
El presente texto realiza una lectura diacrónica de algunas de las voces y problemas de la poesía chilena contemporánea bajo el concepto de imágenes epifánicas. Se entiende esta categoría como la utilización de imágenes que se manifiestan, aparecen o revelan como un modo de iluminar o dar respuesta a una realidad que por sí misma resulta difícil de definir. El corpus de trabajo aborda diversas voces poéticas, desde Gonzalo Rojas hasta nuestros días, lo que genera una discusión respecto a algunas de las formas de concebir la poesía que perduraron durante la segunda mitad del siglo XX y que mutaron con aquellas poéticas más recientes que releen el pasado y visualizan el presente desde un ámbito residual, es decir, en tanto resto. Se concluye que una concepción preponderante de la poesía actual es aquella que no se puede desligar de una función crítica que intenta dar nombre al complejo presente del Chile postdictatorial.
\end{abstract}

Palabras claves: poesía chilena, memoria, postdictadura, residuo, imágenes epifánicas.

\section{Epiphanic Images. Voices of Contemporary Chilean Poetry}

\begin{abstract}
This text is a diachronic reading of some voices and problems in contemporary Chilean poetry under the concept of epiphanic images. This category is understood as the use of images that manifest, appear or reveal as a way to illuminate or respond to a reality that by itself is difficult to define. The corpus addresses diverse poetic voices from Gonzalo Rojas to our current days, generating a discussion about some of the ways of conceiving poetry that lasted during the second half of the 2oth century and that mutated with the most recent poetics that reread the past and visualize the present from a residual scope. It is concluded that a preponderant conception of current poetry is one that cannot be separated from a critical function that attempts to give name to the complex present of postdictatorial Chile.
\end{abstract}

Keywords: Chilean Poetry, Memory, Post Dictatorship, Residue, Epiphanic images.

Recibido: 01/08/2018

Aceptado: 19/01/2019

Este trabajo forma parte del Proyecto Fondecyt $N^{\circ} 1170245$, "Poéticas postdictatoriales. Memoria y neoliberalismo en el Cono Sur: Chile y Argentina". Es una adaptación y reescritura de una conferencia dictada en la Universidad de Concepción el 26 de octubre de 2017 en el marco del $65^{\circ}$ aniversario del Departamento de Español.

Chileno. Doctor en Literatura. Académico de la Pontificia Universidad Católica de Valparaíso, Viña del Mar, Chile. claudio.guerrero@pucv.cl 


\section{Preámbulo e inquisiciones}

El 5 de octubre de 2017, en el Instituto de Literatura y Ciencias del Lenguaje de la Pontificia Universidad Católica de Valparaíso, nos reunimos un grupo de poetas, profesores e investigadores para reflexionar sobre algunas de las problemáticas y tensiones de la poesía chilena del siglo XX. Este ejercicio se ha instaurado desde hace unos años de manera intermitente, entre diferentes actores y organizadores, en la que los estudiantes siempre han sido un primordial protagonista. En esta última ocasión, la presentación central estuvo a cargo del poeta y ensayista Ismael Gavilán, quien, bajo el título "La dificultad de la extrañeza", intentó esbozar un panorama de la poesía chilena reciente, mismo ejercicio que intentaré realizar yo aquí, centrándome en algunas de las, a mi juicio, relevantes voces que han tensionado e instaurado un campo literario sobre el cual la crítica de manera a menudo torpe, siempre como viniendo de atrás, intenta catalogar utilizando diversos epítetos e imágenes, a menudo de connotaciones negativas, si no trágicas: naufragio, desolación, fantasmagoría, espacio baldío, marginalidad, huerfanía, diáspora, etc. Para no ser menos en esto de promover imágenes abarcadoras, he decidido recurrir al término epifánico para referirme a algunas de estas cuestiones, vocablo sobre el cual volveré más adelante.

Antes, quisiera recalcar un par de cosas. Por una parte, hay algo en este ejercicio que siempre es recursivo y circular: volvemos una y otra vez siempre a los mismos, rescatamos una y otra vez ciertas tradiciones y dejamos afuera una y otra vez interesantes voces, particularísimos proyectos estéticos, para llegar a la conclusión de que nos resulta imposible trazar un panorama abarcador. Bajo este punto de vista, este ejercicio pareciera venir de la mano con su propio fracaso, con su propia autodestrucción. Parafraseando a Octavio Paz, se trataría de una "pasión crítica” (1990) que se instaura en la negación a sí misma, que se sabe a sí misma parcial y condenada a una temprana muerte. Pero es sabida, también, y de manera paradójica, que esta recursividad no invoca su nombre en vano. Siempre hay algo que queda. El residuo, el gasto. Un verso. Un poema. La conversación de bar. La fraternidad. O la opción de callar. Algo de este aspecto residual de la poesía es lo que quisiera rescatar acá: cómo una trayectoria crítica, cómo una historia lectora permite aunar distintas huellas de las subjetividades que se expresan en la gran constelación de textos que conforman nuestro firmamento poético. 
No me cabe duda, por ejemplo, que los famosos encuentros organizados por Gonzalo Rojas a fines de los años cincuenta y durante la década del sesenta han dejado a la llamada poesía chilena un acervo del cual tanto poetas como críticos nos hemos servido para tratar de esbozar un grado de comprensión sobre este espacio tachado de oscuro y trágico. Las actas, las transcripciones de conferencias, algunas ponencias, muchos poemas, surgidos de aquellos encuentros literarios que ahora nos parecen muy lejanos funcionan como documentos que colaboran en la persistencia de las "estrellas fijas en un cielo blanco": el armado de una constelación crítica que nos ayude a comprender y comunicar el ejercicio poético que se realiza en estos lares. Pienso, por ejemplo, en la conferencia que dictó Nicanor Parra en el Primer Encuentro de Escritores de 1958, en la Universidad de Concepción, llamada "Poetas de la claridad", en donde explica su anticipatoria poética como contraposición a la en boga poesía hermética. Pienso también en todos los encuentros latinoamericanos que le siguieron durante la década del sesenta, en ese otro encuentro masivo de escritores, el Encuentro Latinoamericano de 1969, en Santiago, Concepción y Valparaíso, y cuya versión porteña es posible de hallar compendiada en esa joya de libro que es el publicado por René Jara en 1971, en Ediciones Universitarias de Valparaíso, llamado El compromiso del escritor, en que conviven junto a poetas y narradores, las voces de obreros, campesinos y estudiantes. El individualismo y la atomización social de hoy parecieran acentuar aún más la nostalgia por aquellas décadas en que la literatura, la música y el cine, y la poesía en particular, procuraban entroncar con la realidad de manera urgente, con un vitalismo que a las nuevas generaciones les debe parecer extraño y a nosotros mismos un ejercicio melancólico.

Conocido es, por otra parte, el lugar común instalado quizás bajo el alero de quienes defienden un purismo poético inmanentista, de que el género poético suele ser refractario a la crítica. Como si la poesía misma se negase a ser crítica. Como si la poesía siguiera siendo el reducto privilegiado de unos pocos dichosos alucinados y no dijera nada sobre la realidad. Como si la poesía fuera una casa para el silencio y la autocomplacencia, para el hermetismo y la videncia, para los ingeniosos artilugios del lenguaje. Para el autismo y el balbuceo incomprensible. Un lugar sagrado. Una iglesia con unos cuantos feligreses. Algo alejado de la vida. De la vida cotidiana. A mi juicio, nada más errado. Nicanor Parra llamó a este tipo de trabajo "poesía sacerdotal”, una poesía mesiánica 
entendida solo para unos pocos. Pienso en ese puñado grande de poemas, demasiado grande, que no podrían tener una vida propia justamente si no recalcaran aquello que Teófilo Cid denominó la "falla de lo real" (1955), ese intersticio de la realidad del cual solo la poesía puede hacerse cargo, pero no para huir de lo real, sino para volver a ella, para incidir en ella, lo que transforma la experiencia de su cotidianeidad. Enumero acá un puñado de esos poemas con los cuales me formé y a los cuales uno siempre vuelve de manera recursiva. Poemas como "Nada" de Carlos Pezoa Véliz, "Explico algunas cosas" de Pablo Neruda, "Los sonetos de la muerte" de Gabriela Mistral, "Carbón" de Gonzalo Rojas, "Retrato de mi padre, militante comunista" de Jorge Teillier o "Canto a su amor desaparecido" de Raúl Zurita, por ejemplo. Cuánto aprendimos de la soledad, del dramatismo de la guerra, del desencanto amoroso, de la infancia larga y siempre viva, del amor filial o del estremecimiento aún palpitante de nuestra herida histórica, a través de estos poemas. Cómo podríamos pensar que la poesía todavía no es escritura y temblor. Si hay algo a lo que la poesía sí me parece que es refractaria es a la lógica del número y del producto, a la lógica del emprendimiento y la competencia, al intento por convertirla en una mercancía dispuesta a ser vendida en las vitrinas, grácil, leve, al servicio de la sociedad del espectáculo y los papers académicos. Vendría a ser, a mi juicio, uno de los últimos reductos del campo de las humanidades que todavía conserva un aura, diríase, de aquello que es inalienable. Habría que pensar si la época benjaminiana de la expropiación de la experiencia no ha tocado aún el campo de la poesía.

Es por esto que, si hay algo que me propuesto hacer desde que tengo la dicha de trabajar en aula es, entre otras cosas, la de tratar de hacer comunicable la poesía. Tratar de iluminar aquellas zonas opacas que la recursividad poética hace difícil de transparentar. La gran poesía chilena que conocemos hoy como tradición ha sido fundada justamente, entre otras cosas, en su interés y motivación por participar de lo público, por tratar de iluminar de manera profana aquello que nos es común y que, a veces, como simples mortales que somos, el lenguaje que tenemos nos parece siempre insuficiente, siempre débil, a menudo impreciso y reducido. En este sentido, como diría Jorge Teillier (1965), la casa de la poesía siempre tiene sus puertas abiertas, siempre recibe a quien la necesita. Y como diría el poeta argentino Sergio Raimondi (2017), siempre está mutando, todo el tiempo invita a ejercitar la lectura como una cuestión relevante que pone en juego las subjetividades, sin dar cabida 
al dogmatismo del discurso unívoco, monocorde, para proporcionarnos información valiosa sobre el presente y sobre el futuro.

Pido disculpas por este largo preámbulo. Es que me parece que el problema de la lectura de poesía es una cuestión crucial porque entiendo que la poesía se muestra a sí misma todo el tiempo como una invitación al ejercicio crítico. Solicito tan solo un último permiso para otra confesión, antes de entrar en el asunto en lo cual me quiero detener hoy. Confieso que, al momento de escribir estas páginas, como cada vez que finalizo un curso de poesía chilena o de poesía hispanoamericana, no puedo dejar de sentir la sensación de que injustamente he omitido un nombre, un poemario, un movimiento, un poema o un verso que ilumine estos mundanos asuntos. Como si la poesía siempre fuera desborde, un generoso discurso que nunca se agota. Y es que pareciera que Gavilán tuviera algo de razón cuando señala que la fantasmagórica historia de la poesía chilena se nos revela como una fuerza centrífuga, una antitradición pluralista en que es posible hallar una multisistémica coexistencia de vetas poéticas. Los fantasmas, por lo demás, aparecen y desaparecen, a veces se dejan ver, la mayor parte del tiempo permanecen en un cautiverio silencioso, una “zona muda”, diría Enrique Lihn (1989). Por lo demás, los espectros, como señala Jacques Derrida (1995), cuando vuelven lo hacen para mover los signos, para instaurar una pesquisa, un desciframiento, un desafío: ¿serás capaz de leerme? La venida de los espectros genera una revuelta: una remoción de los signos. Estos signos removidos es lo que yo llamo imágenes epifánicas: imágenes que se manifiestan, aparecen o revelan para darnos cuenta de un aspecto de lo real. Constructos poéticos pensados a sí mismos como un objeto cultural complejo cuyo norte no es otro que la intervención de lo real.

\section{Voces para remover}

Habiendo puesto sobre aviso acerca de esta cuestión que me parece fundamental, quisiera detenerme en algunas voces poéticas sobre las cuales he estado indagando en el último tiempo, que me parece, vienen a cumplir esta función de remoción. Porque la remoción es un mudar algo y también es conmover y alterar. Una poesía que no emociona, decía César Vallejo (2003), no es poesía. Si la poesía no nos dice nada, es pura artimaña, puro deleite para unos cuantos. La poesía chilena que en par- 
ticular más me interesa es aquella que promueve la alteración, la muda o el cambio, aquella que configura un tipo de lector, al mismo tiempo que busca emocionar. Esta función afectiva y política de la poesía creo que es algo que posibilita, justamente, un punto de encuentro, la autoconciencia de su comunicabilidad.

Como señalé, pretendo condensar aquí algunas notas y apuntes que dan cuenta más bien de una especie de relación personal, a sabiendas de la imposibilidad de ser exhaustiva o representativa. Se trata tan solo de algunos puntos fijados en el enorme mapa que es la poesía chilena, un mapa en permanente construcción, móvil e inestable, esquiva y elusiva.

Y creo que un buen punto de partida es señalar el aporte singularísimo que algunos poetas de mediados de siglo XX construyeron para las décadas venideras. Me refiero, en particular, a las líneas trazadas por poetas como Nicanor Parra, Gonzalo Rojas, Jorge Teillier y Enrique Lihn. A menudo, cuando leo textos de los poetas de las décadas venideras, se me revela como algo natural el hecho de que en casi todos es posible hallar guiños, influencias y parentescos con estos poetas. Hay algo en ellos que los vuelve fundacionales. Pero no con vetas exclusivas. Hay momentos de la poesía de Teillier que son lihneanos. Gonzalo Rojas tiene algo de los tres. Y Lihn es hermano de Parra. Esto, sin contar por supuesto, un montón de otras líneas posibles de rastrear, las líneas fundadoras de Pezoa Véliz, Mistral o De Rokha, o toda la influencia de la poesía objetivista anglosajona que tan marcada presencia tiene en algunos poetas actuales como Germán Carrasco, por ejemplo. Y así, podríamos jugar a trazar una suerte de sociograma que nos muestre la trama de interrelaciones poéticas que se dan entre los diversos actores de la poesía chilena. De todos esos juegos, el que más me gusta es la de armar selecciones de fútbol. Hace poco un usuario literario de Twitter compartió su oncena y luego vinieron muchas más como respuesta. La que más me gustó empezaba con Vicente Huidobro de arquero, Pablo de Rokha de líbero, Rodrigo Lira de contención y Mauricio Redolés de centrodelantero.

Con esto, apunto al hecho, al parecer innegable, de que la llamada historia de la poesía chilena pareciera ser una suerte de palimpsesto, un texto escrito sobre otro y otro y otro. Teniendo claro de que se trata de un juego de nunca acabar, de todos los autores aquí nombrados, quisiera detenerme en uno: Gonzalo Rojas. 
Conocí la poesía de Gonzalo Rojas a través de esa curiosa antología que publicó Fondo de Cultura Económica por allá por los años noventa. Y digo curiosa porque desde el título mismo Antología del aire (1996) me encontré con una escritura original, clara, limpia y potente, con la cual no me sentía familiarizada hasta entonces. Qué era eso del aire. Cómo entender el aire. Qué cosas trae el aire. Releyendo dicho libro, volví a recordar varios poemas reveladores, epifánicos, de esos poemas que resuenan en la memoria a causa de la remoción. Estaban dormidos allí y su reaparición me hizo pensar en cuántos cruces son posibles de realizar con los poetas venideros. Cuántos poetas de las generaciones siguientes tienen algo de Gonzalo Rojas en sus versos. O, dicho de otra manera, cuántos deudos reconocidos y no reconocidos son susceptibles de ser vinculados a esta veta poética. Leo, por ejemplo, el "Monólogo del padre con su hijo de meses" o el cuento "Agua de arroz", ambos de Enrique Lihn, y algo de eso ya estaba en "Crecimiento de Rodrigo Tomás”: “Ahora me pregunto cuál será el límite de tu carácter” (26); “Tu raíz es una estrella más pura que el peligro" (26). Reconozco aquí, por ejemplo, a esa masculinidad nueva de mediados de siglo enfrentada al insólito hecho de la paternidad, al descubrimiento de una realidad nueva y asombrosa que en el caso de Lihn tienta al fracaso, así como en Rojas tentaba al misterio. Reviso, por ejemplo, esos bienaventurados y dichosos poemas que conforman Variaciones sobre el tema del amor y de la muerte de Alfonso Alcalde (1991), esos poemas de carne rechinada, y se me asoman esos apasionados, estremecedores poemas sobre el amor y la belleza, poemas de cuerpos hambrientos y aire insaciable, exquisiteces del lenguaje como "Perdí mi juventud”, "Qedeshím qedeshóth”, “¿Qué se ama cuando se ama?", "El fornicio” o "Elegía”. Tomo de este último los siguientes versos:

Acabo de matar a una mujer

después de haber dormido con ella una semana, después de haberla amado con locura desde el pelo a las uñas, después de haber comido su cuerpo y su alma, con mi cuerpo hambriento. (38)

Pienso, por ejemplo, en cuántos textos poéticos habrán surgido después de leer "Contra la muerte". Pienso en todo lo que habrán aprendido de Gonzalo Rojas los poetas del grupo Arúspice, cuánto del poeta de Lebu hay en Floridor Pérez, en Jaime Quezada, en Gonzalo Millán. Y en poetas de décadas posteriores: cuánto de Gonzalo Rojas 
hay en la poesía de Carlos Cociña, de Sergio Muñoz o de Antonia Torres, cuyo libro de 1999, Las estaciones aéreas, pareciera establecer un vínculo celeste, genealógico, con estos versos de Rojas, del poema "La palabra":

Un aire, un aire, un aire

un aire,

un aire nuevo:

no para respirarlo

sino para vivirlo. (77)

Pienso que Gonzalo Rojas es uno de esos poetas vestibulares que, por haber coexistido con otros grandes poetas, ha permanecido aún en cierto espacio intersticial, aún como en suspenso, a la espera de una revisión crítica más profusa. Algo similar ocurre con figuras como Delia Domínguez o Efraín Barquero. En la gran mesa de conversación de la poesía chilena, amplia y generosa, estos poetas también proponen direcciones y señales de ruta.

A partir de este pequeño acto de homenaje, quisiera rescatar cinco vertientes de la poesía chilena contemporánea que particularmente me parecen relevantes y que contribuyen a configurar un panorama un poco más amplio de algunas de sus voces, procedimientos textuales y temas, desplegados en los últimos cuarenta a cincuenta años de producción poética.

Me referiré, en primer lugar, a aquellas poéticas que se proponen realizar una crítica al avance erosionador de una modernidad desfasada, equívoca y desigual, a la eclosión de la sociedad de consumo y del espectáculo a partir de los años cincuenta y sesenta, a la vida enajenada de la urbe en contraposición a la que se experimenta en la provincia y al rol que juegan los medios de comunicación en las sociedades contemporáneas. Este poema de Jorge Teillier "Cuando todos se vayan a otros planetas" (1992), me parece ilustrativo:

Cuando todos se vayan a otros planetas

yo quedaré en la ciudad abandonada

bebiendo un último vaso de cerveza,

y luego volveré al pueblo donde siempre regreso

como el borracho a la taberna

y el niño a cabalgar

en el balancín roto. (76) 
Tenemos aquí a un sujeto que prefiere experimentar la ciudad desde el encierro de un bar y no desde sus lugares abiertos, sus calles, parques o avenidas. El bar es el refugio para una ciudad percibida apocalípticamente, donde no es posible hallar algún valor positivo. Al mismo tiempo, se constituye como lugar de paso para llegar al pueblo donde siempre se regresa para allí detenerse a hablar con antiguos compañeros de escuela, caminar sin prisa y nuevamente encerrarse a escuchar canciones antiguas. Hay aquí una oposición que está delineada en la promesa de progreso que trae consigo la carrera espacial versus los espacios del ahora que se presentan ruinosos, ajados u oxidados. El sujeto opta por el espacio ruinoso. Un presente degradado por el paso del tiempo, para el cual todo discurso de futuro no suena más que un bello cuento de ciencia ficción sacado de Ray Bradbury. Podemos apreciar en este poema, y en general en toda la poesía de Teillier, una actitud del hablante que busca construir un mundo poético alternativo respecto al fluir de los discursos modernizadores y los avances tecnológicos, una poesía de la sencillez que funciona como contratexto de lo teórico, masivo y productivo, que prefiere detenerse a avanzar, y que descree de las ideas de progreso, en una suerte de antiflânuer o flâneur de campo cuyo especial ámbito de realización poco tiene que ver con lo que la sociedad de masas considera útil, atractivo o rentabilizador.

Esta actitud de preferir detenerse, de descreer de los discursos modernizadores y de propender al refugio la percibo como una constante potente en la poesía chilena, en especial, a través de una reactualización que yo denominaría como neolarismo, ahora bajo nuevas condiciones sociohistóricas, específicamente algunas poéticas que, ante el efecto demoledor de las políticas neoliberales, plantean un repliegue que busca resistir dicho proceso y en especial desde centros no urbanos. El repliegue se da en una suerte de opción por la vida más pausada de provincia y por hacer de los circuitos extracapitalinos un habitar la poesía alejados de los focos mediáticos. Veo en esta opción una suerte de proceso de descentralización poética, un proceso de fuga que impide la contaminación por parte de los nocivos efectos de la vida posmoderna. Algo de esto está muy bien reunido en el gran trabajo ensayístico de Felipe Moncada, Territorios invisibles (2016), en el que compendia a un destacado grupo de poetas de provincia, definidos a sí mismos en base a su nulo interés por participar de una metrópoli centralizante. Y se me vienen a la memoria algunos poemas de David Bustos, Fernando Rivera, 
Florencia Smiths, Jorge Polanco, Ricardo Herrera, Cristian Cruz, Cristian Gómez, Bernardo González, Rodrigo Arroyo, Daniel Rojas Pachas, entre otros. Todos, en cierto modo, herederos de la estética teilleriana de una realidad secreta, donde la naturaleza todavía no ha sido arrasada del todo y la vida todavía puede ser en cierto modo apacible, a pesar de que ese bar teillieriano ya casi no existe o está contaminado por el ruido constante del televisor encendido, por lo que como refugio ha sido reemplazado por otras posibilidades de colectividad como, por ejemplo, las editoriales independientes.

En segundo lugar, me parecen interesantes aquellas poéticas que se proponen la exploración estética a partir de la ampliación de los códigos tradicionalmente asignados a la poesía. Destaco especialmente aquellas búsquedas que intentan incorporar lo visual, lo plástico y sonoro, que establecen relaciones con procedimientos técnicos que toman prestado del cine, la fotografía, la composición musical o la pintura, y que han sido agrupados por la crítica bajo el concepto de neovanguardia a partir de los años sesenta y setenta. Muchos de los textos de Gonzalo Millán, Juan Luis Martínez, David Rosenman Taub, Rodrigo Lira, Raúl Zurita, Carmen Berenguer o Alexis Figueroa pueden leerse considerando esta dimensión, como también la obra poética de Mauricio Redolés o la estética neobarroca de Diego Maqueira y el Enrique Lihn de El Paseo Ahumada (1983). Esta vertiente, además, puede entroncarse con algunas manifestaciones actuales de la poesía digital, la poesía experimental o la poesía sonora, en poetas como Luis Correa Díaz, Felipe Cussen, Carlos Soto Román, Martín Gubbins, o, incluso, en agrupaciones como La Orquesta de Poetas. Podríamos considerar este fragmento del poema "La ciudad", de Gonzalo Millán (1997) como un texto inaugural:

11 de septiembre.

Regresan aviones con refugiados.

Chile es un país democrático.

Las fuerzas armadas respetan la constitución.

Los militares vuelven a sus cuarteles.

Renace Neruda.

Vuelve en una ambulancia a Isla Negra.

Le duele la próstata. Escribe.

Víctor Jara toca la guitarra.

Canta.

Los discursos entran en las bocas. 
El tirano abraza a Prat.

Desaparece.

Prat revive.

Los cesantes son recontratados.

Los obreros desfilan cantando

¡Venceremos! (86)

Me interesa destacar de este poema el procedimiento técnico utilizado por Millán, que nos recuerda a la idea de una acción en reversa, como una película en VHS que se está rebobinando. Al mismo tiempo, el uso de versos que recurren a una misma fórmula de sujeto, verbo y predicado simple provoca un efecto de normatividad sonora que convierte a este poema de carácter eminentemente descriptivo en una suerte de banda mecánica de ritmo regular, monocorde. Este dispositivo poético que exhibe el artificio de su montaje choca, al mismo tiempo, de manera trágica con el contenido mismo del poema y la imposibilidad de deshacer la historia, haciendo del tiempo verbal del "Venceremos" profético y utópico, una aún más dolorosa derrota que vuelve a abofetear el rostro. Hay aquí una concepción de la poesía que está segura de sus límites al mismo tiempo que deposita su fe en nuevos códigos que permiten ampliar la experiencia estética, haciéndola más compleja y completa, en la urdimbre entre forma y contenido. La búsqueda de nuevos lenguajes y formas de expresión resultan aquí vitales para entender la poesía como un proceso de trabajo continuo, una indagatoria que no se detiene y que, en el caso del mismo Millán, se puede apreciar en las diferentes versiones que mantuvo de muchos de sus textos, como en el mismo caso del poema "La ciudad".

En tercer lugar, una vertiente reconocida lo constituyen las poéticas de la memoria, que rescatan y poetizan las heridas y traumas del pasado con un sentido para el presente. Son las llamadas poéticas de dictadura, desarrolladas principalmente por actores poéticos que ocuparon un rol relevante durante el periodo de insilio literario y que fueron testigos directos de la violencia política de la dictadura cívico-militar. Es el caso, también, de autores que se fueron al exilio. Recuerdo, en este momento, a poetas como Javier Campos y Waldo Rojas. Y me interesan en particular algunos de los textos de Carmen Berenguer, Elvira Hernández, Raúl Zurita, Floridor Pérez y Aristóteles España, entre otros, en cuyos poemas es posible hallar el testimonio, la resistencia y el dolor, expresados de manera estremecedora, en algunos casos, y con ironía y humor, en otros. 
Rescato este de Floridor Pérez, de Cartas de prisionero (1990), poemario que alude a la prisión del poeta en el campo de concentración de Isla Quiriquina:

Mientras reflexionaba su séptima jugada

un cabo gritó su nombre desde la guardia.

—iVoy! — dijo

pasándome el pequeño ajedrez magnético.

Como no regresara en un plazo prudente

anoté, en broma: Abandona. (22)

Vemos aquí cómo la experiencia de la prisión y la ejecución política es estetizada de manera irónica y trágica a la vez, convirtiendo un deporte de culto como el ajedrez en el núcleo temático que permite hablar sobre el destino de los prisioneros, haciendo de la muerte de uno de ellos algo azarosa y penosamente extraordinario que pudiera tener, al menos, un sentido distinto al de la mera muerte numérica. En esa conjunción de cotidianeidad y sentido de la historia se juega la posibilidad de dar voz y rostro, nombre y lugar, a quienes por razones políticas sufrieron persecución, tortura o muerte. Todo este poemario de Floridor Pérez, publicado en México en 1984, gira en torno a la violencia, el absurdo y la denigración humana, utilizando procedimientos que van mucho más allá de lo testimonial, procedimientos que incluyen la incorporación de cartas, portadas de diarios intervenidas por el autor y fotografías que complejizan la recepción de la obra. Es posible encontrarse allí, también, como en toda la poesía contemporánea, una poética, su condición autorreflexiva y metaliteraria, que busca el asombro, la ironía y la risa de filiación parriana.

Finalmente, hecha esta breve rememoración de algunos de los más entrañables poemas de Gonzalo Rojas, y cómo se manifiestan de manera continua o discontinua algunos tópicos y procedimientos poéticos que, a mi juicio, tienen aún plena vigencia, dejo para el final las últimas dos vertientes sobre los cuales llevo ya varios años investigando de manera más detenida y que, desde mi punto de vista, resaltan dentro del panorama de la poesía del siglo XXI, para articular una reflexión en torno al paisaje postdictatorial aún vigente. Y propongo detenerme en dos poemas, dos poemas que hablan del tiempo actual y del pasado reciente de manera crítica. 
El primer poema es de Jaime Pinos, se titula "Música ambiental" y pertenece a su poemario Almanaque (2010):

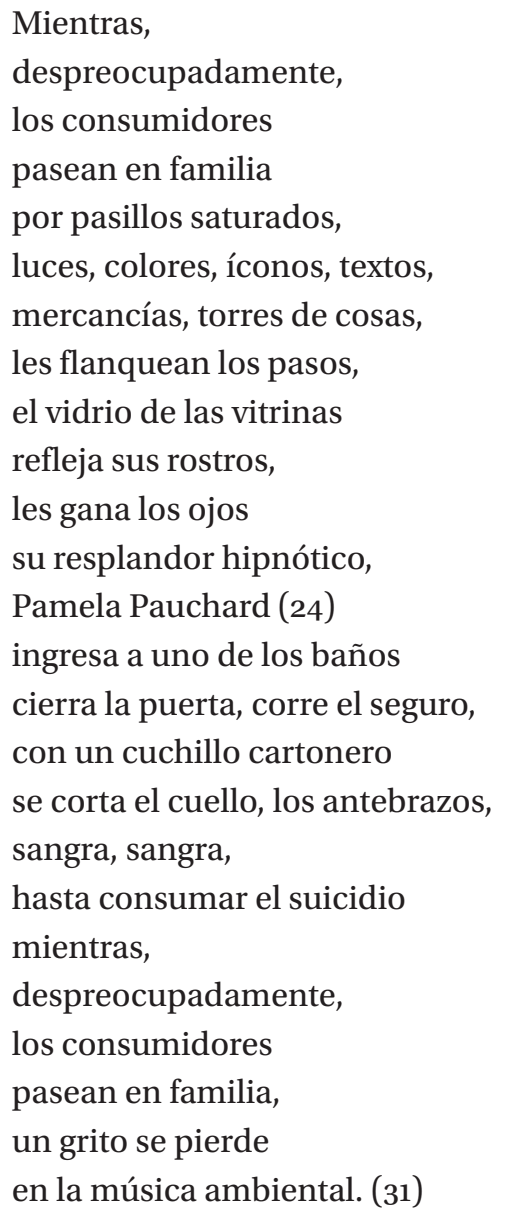

El ejemplo me parece decidor para dar cuenta de aquellas poéticas que, de una manera declarativa, se proponen desarrollar aquello que Enrique Lihn (1997) llamó una "poesía situada”. Poéticas de índole sociopolítica, entroncadas en la historia, como crítica del presente. Poesía documental, que vuelve al objetivismo. Poética del sujeto observador, testigo. Destaco aquí, entre otros, a José Ángel Cuevas, Raúl Hernández, Alejandra González o Elvira Hernández, en un tipo de hacer poesía que hacia atrás nos vincula con algunas de las producciones documentales de Floridor Pérez, Raúl Zurita, Rodrigo Lira o Gonzalo Millán, por ejemplo. En muchos de los textos de estos poetas es posible hallar la derrota de la Transición y el vacío paisaje del neoliberalismo a la chilena puestos en 
tensión desde la resistencia poética, desde una trinchera escritural que se resiste a que la aplanadora del exacerbado economismo de la vida cotidiana y la desmemoria minen la experiencia poética y la posibilidad de construir una sociedad diferente, lo más lejano posible a valores entroncados en nuestra sociedad como la fe ciega en el progreso y el consumismo. Se trata de poetas-cronistas que denuncian la pobreza, la desigualdad y las políticas del olvido, que rescatan las vidas mínimas de los anónimos y que son conscientes de que la poesía, a la par de su manida insignificancia o su intrascendencia, debe ocupar un espacio relevante en la vida social. Porque leer poesía y escribir poesía es casi la misma cosa.

Este poema, en particular, nos muestra algunas de las heridas o fisuras del sistema neoliberal: violencia, desvinculación afectiva entre las personas, desconfianza, egoísmo e individualismo. El contraste entre un alegre e hipnótico consumismo versus la depresión o angustia existencial se retrata en este texto-crónica, texto descriptivo, impersonal, que alude al suicidio de una joven el 4 de mayo de 2006 en el mall Alto Las Condes de la ciudad de Santiago. La exhibición de estas "fallas de la realidad" del modelo neoliberal junto a otras como la precariedad laboral, el excesivo endeudamiento, la sensación de inseguridad, la falta de memoria y justicia respecto a las víctimas de la dictadura, los mundos de fantasía que promueve la publicidad, son algunos de los elementos que terminan por configurar un trabajo escritural que asedia deliberadamente el tiempo actual.

Como señala el geógrafo y teórico social inglés David Harvey en “Capitalismo: la fábrica de la fragmentación” (2007), el capitalismo y su vertiente más extrema, el neoliberalismo, aplicado con escasas restricciones en el Cono Sur a lo largo de las últimas cuatro décadas, es una fábrica de fragmentación y enajenación de los sujetos, un motor de descentramiento e inestabilidad. Creo que estas poéticas que cuestionan el neoliberalismo buscan realizar un juicio estético-crítico a estas formas de expresión del capitalismo, construyendo estéticas que documentan y problematizan estos procesos de degradación. Se trata de un tipo de escritura que se está ejecutando a la par del tiempo actual, que releva la función social y política de la poesía y la literatura en tiempos de precarización y fragmentación, espectáculo y farándula, narcisismo y desinterés por lo común. Emoción, remoción y acción: un programa estético-político para los tiempos que corren. Pero, al mismo tiempo, 
sin mayor pretensión, a sabiendas, de que la poesía en el fondo no sirve para nada. Es importante, es grave. Por supuesto. Pero a otros con ese cuento. La poesía como negación de sí misma.

El segundo poema pertenece a Alejandra del Río y se llama "Resiliencia", inserto en su poemario material mente diario (2009), del cual cito dos fragmentos:

Nunca jugamos a ser madres

sólo en historias de terror

Abandonaban niños en la puerta de la casa

vivos y muertos

debíamos enterrarlos

formar un sindicato de huérfanos

implantar su reino de justicia

\section{(...)}

La muerte era nuestra niñera de día y de noche bebía en el salón junto a los conspiradores

La muerte se sentaba a la cabecera vigilaba compadecida su guadaña se quedaba quieta alcanzaba sólo a rozar algunos rizos algunos miembros prescindibles. (61-62)

Este texto forma parte de las llamadas poéticas de infancia, muy presentes en los poetas de mi generación, en quienes fuimos niños y crecimos en dictadura, sujetos descentrados, desacomodados, que interrogamos el pasado para encontrarle un sentido al presente o que vivimos el presente a partir de sus desajustes. Se trata de poéticas de postdictadura que han tomado como eje la niñez, para expresar desde allí, muchas veces en clave autobiográfica o como autoficción, las huellas de la violencia política y simbólica que de manera casi invisible permanecen en un presente lleno de residuos y restos de un pasado vivido a medias o de oídas. Destaco aquí a poetas como Tamym Maulén, Gustavo Barrera, Rosabetty Muñoz, Christian Formoso, Angélica Panes, entre muchos otros, quienes en sus textos impregnan de indicios, marcas y afectos, muchas de las experiencias vividas en un contexto de violencia 
y que ahora vienen a recuperar para obtener desde allí un sentido de vida orientador. Las referencias de este tipo de poéticas no siempre tienen como marco explícito el contexto dictatorial, pero por las fechas de nacimiento de estos poetas -años setenta y ochenta- es posible encontrar un paisaje de fondo que ineludiblemente impregna sus textos, situando las trayectorias de vida de los sujetos que aparecen aquí ficcionalizados, en trances de dificultad familiar en medio de un contexto social siempre inestable, borroso o desestructurado.

Reconozco en este poema la idea de una infancia abandonada, semiclandestina y acechada por la muerte. El poema nos habla de niños encerrados, insertos en una historia de terror, huérfanos, que desconfían de los otros niños porque sus padres son militares. Niños acostumbrados a compartir con adultos semidesconocidos, que se quedan a dormir durante el toque de queda. Niños que crecen sabiendo que hay cosas que no se pueden decir, que hay objetos como los grabados que no pueden salir a la luz pública, niños acostumbrados a callar y a vivir, en definitiva, una historia que ahora, desde la adultez, es vista con extrañeza y asombro, desde la sobrevivencia, desde la figura de un resiliente: aquel que ha sido capaz de adaptarse a estados o situaciones adversas. Otra acepción del término resiliencia, además, dice: "Capacidad de un material, mecanismo o sistema para recuperar su estado inicial cuando ha cesado la perturbación a la que había estado sometido" (RAE). Hay en un poema como este, entonces, un proceso de reconstrucción de las historias de vida de los sujetos. Interrogaciones del pasado y sus vestigios, aquello residual en palabras de Nelly Richards (1998) que siempre aflora para incomodar. Se trata de poéticas que activan procesos de memoria que buscan recomponer la historia personal y colectiva. Poéticas del duelo que creativamente buscan nuevos significados y modos de existencia tendientes a la construcción de una sociedad otra. Creo que este tipo de textos ha sido una constante en los últimos años, en un fenómeno que también se ha visto en la narrativa reciente, un tipo de estética que todavía busca renovar sus modos de expresión, para lo que recurre en algunos casos a la ironía y la parodia.

\section{Para seguir indagando}

Como señalé, el panorama es muchísimo más amplio. Estas son tan solo algunas de las voces recientes que me parecen interesantes. 
Dejando de lado a toda la camada de poetas que hoy tienen entre veinte y treinta años, y sobre la cual ya existen incipientes aproximaciones críticas, hay otras poéticas sobre los cuales pretendo dejar tan solo algunos apuntes. Hay un grupo de poetas, por ejemplo, que han intentado articular una poética que renueva las formas tradicionales de la poesía, recurriendo al metro regular, la rima consonante y formas clásicas como el soneto. De este grupo, destaco en particular la de Rafael Rubio, hijo de y nieto de otros dos insignes poetas, Armando y Alberto, respectivamente. Es posible de apreciar en la poesía de Rubio un gran conocimiento de la historia poética, así como la búsqueda de una sonoridad y un ritmo que impregne de prestancia musical al texto poético. El poema como soporte, como materialidad. Me parece que otros autores particularmente preocupados de una construcción cuidada del verso, lo que se traduce en sólidos poemas bien urdidos, pequeñas piezas exquisitas, son muchos de los trabajos que exhiben hasta ahora autores como Javier Bello, Leonardo Sanhueza y Germán Carrasco, por nombrar algunos.

Asimismo, hay otras poéticas que observo aún no han acabado sus posibilidades críticas. En el último tiempo, por ejemplo, he estado indagando sobre la vanguardia chilena. Me parece que hay allí todavía un trabajo por hacer en lo referido a lecturas críticas que permitan abordar estéticas no canónicas como las del Manifiesto Agú, el Runrunismo, Rosa Náutica e incluso La Mandrágora. Del mismo modo, hay autores como Carlos Pezoa Véliz, Teresa Wilms Montt y la familia de Rokha que suelen quedar fuera de algunas listas de poetas de las primeras décadas del siglo XX, así como se sigue tildando de hermética las poéticas de autores como Humberto Díaz-Casanueva o David Rosenman Taub. Pienso que también autores de filiación popular, como Roberto Parra, y toda la obra de Víctor Jara y Violeta Parra debiese tener más estudios críticos. La reciente edición de la poesía de Violeta Parra por Ediciones Universidad de Valparaíso (2018) me parece un tremendo rescate de su obra, aún por (re)descubrir. Y qué decir de la obra de Gabriela Mistral. Las recientes publicaciones de textos inéditos abre toda una fuente de exploración que dará mucho de que hablar de nuestra más valiosa poeta chilena. La vuelta a ese pasado poético, creo, es algo que posibilita renovar la tradición, a la cual nunca debemos dar por anclada. La llamada poesía mapuche, finalmente, ese gran sistema literario que pone en cuestión voces de filiación indígena, también es aún un campo no agotado, sobre 
todo en virtud del histórico conflicto con el Estado chileno, más vigente que nunca.

En definitiva, se trata de algunas de las posibles líneas de fuga de la poesía chilena contemporánea. Cada uno de estos lugares constituye un gran tema en sí mismo, de profundos alcances analíticos, imposible de acotar aquí. Asimismo, los ejemplos dados resultan escasos. Por otra parte, sin duda debe haber otras vertientes tanto o más interesantes que estas y que por las limitaciones de toda crítica no he considerado aquí. De todas formas, de lo que he pretendido dejar constancia acá es simplemente de la reunión de algunas de las huellas lectoras sobre las cuales he estado trabajando en los últimos años y que se presentan a los ojos del crítico como imágenes epifánicas, como voces reveladoras, que desde la poesía permiten colaborar en la comprensión y entendimiento del complejo tiempo presente. Insisto en rescatar esta función de la poesía, en su capacidad de remoción. Voces, formas, registros, procedimientos que nos proporcionan algunas luces para el presente y lo porvenir.

\section{Referencias bibliográficas}

Alcalde, Alfonso. Variaciones sobre el tema del amor y de la muerte. Santiago, El Árbol de la Palabra, 1991.

Cid, Teófilo. Niños en el río. Santiago, Ediciones Espadaña, 1955.

Del Río, Alejandra. material mente diario. Santiago, Cuarto Propio, 2009.

Derrida, Jacques. Espectros de Marx. Madrid, Editora Nacional, 1995.

Gavilán, Ismael. "La dificultad de la extrañeza”. Conferencia dictada el 5 de octubre de 2017 en el Instituto de Literatura y Ciencias del Lenguaje, Pontificia Universidad Católica de Valparaíso.

Harvey, David. "Capitalismo: la fábrica de la fragmentación”. Espacios del capital. Madrid, Akal, 2007, pp. 137-143.

Jara, René. El compromiso del escritor. Valparaíso, Ediciones Universitarias de Valparaíso, 1971.

Lihn, Enrique. Diario de muerte. Santiago, Universitaria, 1989.

El circo en llamas. Santiago, LOM, 1997.

Millán, Gonzalo. Trece lunas. Santiago, Fondo de Cultura Económica, 1997. 
Moncada, Felipe. Territorios invisibles. Valparaíso, Ediciones Inubicalistas, 2016.

Parra, Nicanor. “Poetas de la claridad”. Atenea, no. 500, 2009, pp. 179-183.

Paz, Octavio. Los hijos del limo. Barcelona, Seix Barral, 1990.

Pérez, Floridor. Cartas de prisionero. Concepción, Lar, 1990.

Pinos, Jaime. Almanaque. Santiago, Lanzallamas, 2010.

Real Academia de la Lengua Española. “Resilencia”. Diccionario de la lengua española. 23a Ed. Consultado en http://www.rae.es/ rae.html

Raimondi, Sergio. "Poesía mundial desde la revolución industrial: 200 años de analogías asimétricas". Conferencia dictada el 25 de octubre de 2017 en el Instituto de Literatura y Ciencias del Lenguaje, Pontificia Universidad Católica de Valparaíso.

Richard, Nelly. Residuos y metáforas. Ensayos de crítica cultural sobre el Chile de la Transición. Santiago, Cuarto Propio, 1998.

Rojas, Gonzalo. Antología del aire. Santiago, Fondo de Cultura Económica, 1996.

Teillier, Jorge. “Los poetas de los lares”. Boletín de la Universidad de Chile, no. 56, 1965, pp. 48-62.

Los dominios perdidos. Santiago, Fondo de Cultura Económica, 1992.

Torres, Antonia. Las estaciones aéreas. Valdivia, Ediciones Barba de Palo, 1999.

Vallejo, César. "Poesía nueva”. Las vanguardias literarias en Hispanoamérica. Coord. Hugo Verani. México D.F., Fondo de Cultura Económica, 2003, pp. 213-214. 